\title{
THE TRUE CONCEPTION OF UNILATERAL CONTRACTS
}

Suppose A says to $B$, "I will give you $\$$ roo if you walk across the Brooklyn Bridge," and B walks-is there a contract? It is clear that $A$ is not asking $B$ for $B$ 's promise to walk across the Brooklyn Bridge. What $\mathrm{A}$ wants from $\mathrm{B}$ is the act of walking across the bridge. When $B$ has walked across the bridge there is a contract, and $A$ is then bound to pay to $B$ \$1oo. At that moment there arises a unilateral contract. A has bartered away his volition for B's act of walking across the Brooklyn Bridge.

When an act is thus wanted in return for a promise, a unilateral contract is created when the act is done. It is clear that only one party is bound. $B$ is not bound to walk across the Brooklyn Bridge, but $A$ is bound to pay $B$ \$1oo if $B$ does so. Thus, in unilateral contracts, on one side we find merely an act, on the other side a promise. On the other hand, in bilateral contracts, A barters away his volition in return for another promise; that is to say, there is an exchange of promises or assurances. In the case of the bilateral contract both parties, $A$ and $B$, are bound from the moment that their promises are exchanged. Thus, if A says to $B$, "I will give you $\$ r o 0$ if you will promise to walk across the Brooklyn Bridge," and $B$ then promises to walk across the bridge, a bilateral contract is created at the moment when $\mathrm{B}$ promises, and both parties are thereafter bound. The conception of the bilateral contract, while presenting various theoretical difficulties, has in the main been developed by the courts with a reasonable degree of precision; but the unilateral contract has proven a stumbling block to nearly every court which has had occasion to consider the question. In no domain of the law are the opinions marked by such lack of clear thinking. ${ }^{2}$

It is plain that in the Brooklyn Bridge case as first put, what $A$ wants from $B$ is the act of walking across the Brooklyn Bridge. A does not ask for B's promise to walk across the bridge and $B$ has never given it. $B$ has never bound himself to

\footnotetext{
${ }^{1}$ See Los Angeles Traction Co. v. Wilshire (1902) I35 Cal. 654; Plumb v. Campbell (I8go) I29 Ill. ror.
} 
walk across the bridge. A, however, has bound himself to pay $\$$ Ioo to $B$, if $B$ does so. Let us suppose that $B$ starts to walk across the Brooklyn Bridge and has gone about one-half of the way across. At that moment $A$ overtakes $B$ and says to him, "I withdraw my offer." Has B then any rights against A? Again, let us suppose that after A has said "I withdraw my offer," B continues to walk across the Brooklyn Bridge and completes the act of crossing. Under these circumstances, has $B$ any rights against $A$ ?

In the first of the cases just suggested, A withdrew his offer before $B$ had walked across the bridge. What $\mathrm{A}$ wanted from $B$, what $A$ asked for, was the act of walking across the bridge. Until that was done, B had not given to $A$ what $A$ had requested. The acceptance by $B$ of $A$ 's offer could be nothing but the act on B's part of crossing the bridge. It is elementary that an offeror may withdraw his offer until it has been accepted. ${ }^{2}$ It follows logically that $A$ is perfectly within his rights in withdrawing his offer before $B$ has accepted it by walking across the bridge- the act contemplated by the offeror and the offeree as the acceptance of the offer. A did not want $B$ to walk half-way across or three-quarters of the way across the bridge. What $A$ wanted from $B$, and what $A$ asked for from $B$, was a certain and entire act. $B$ understood this. It was for that act that $A$ was willing to barter his volition with regard to $\$$ Ioo. B understood this also. Until this act is done, therefore, $A$ is not bound, since no contract arises until the completion of the act called for. Then, and not before, would a unilateral contract arise. Then, and not before, would $\mathrm{A}$ be bound.

2 Payne v. Cave (1789) 3 T. R. 148. The authorities are collected in Williston, Wald's Pollock on Contracts, pp. 27, 28. I cannot agree with Mr. Williston's suggestion that "an option or offer under seal is irrevocable during the time which it specifies." Any offer of any kind may be revoked at any moment before acceptance, but the revocation of an offer of the nature referred to by $\mathrm{Mr}$. Williston may subject the offeror to an action for damages if the right of revocation be exercised. In other words, the contract whereby the offeror agrees to hold an offer open for a specified time is broken when the offer is revoked, and the breach, like all breaches of contract, is actionable. This is quite a different proposition, however, from stating that offers of this kind are "irrevocable." No offer is irrevocable. Thus, if A gives B $\$ 100$ for B's promise to keep a certain offer open for one week, B thereby contracts to do this. B may revoke his offer, but if he does so, he runs the risk of a damage suit by $A$. 
The objection is made, however, that it is very "hard" upon $B$ that he should have walked half-way across the Brooklyn Bridge and should get no compensation. This suggestion, invariably advanced, might be dismissed with the remark that "hard" cases should not make bad law. But going a step further, by way of reply, the pertinent inquiry at once suggests itself, "Was B bound to walk across the Brooklyn Bridge?" The - answer to this is obvious. By hypothesis, B was not bound to walk across the Brooklyn Bridge. $B$ had never surrendered his volition with regard to walking across the bridge. $B$ had never promised A that he would walk across the bridge. There had been no interchange of promises. A was bound to pay $\mathrm{B} \$ 100$ in the event that $B$ should walk across the bridge, but $B$ had not bound himself to walk. It follows that at the moment when $A$ overtook $B$, after $B$ had walked half-way across the bridge, that $B$ was not then bound to complete the crossing of the bridge. $B$, on his side, could have refused at that time, or at any other time, to continue to cross the bridge without making himself in any way legally liable to $A$. If $B$ is not bound to continue to cross the bridge, if $B$ is will-free, why should not $A$ also be will-free? Suppose that after B has crossed half the bridge he gets tired and tells $A$ that he refuses to continue crossing. B, concededly, would be perfectly within his rights in so speaking and acting. A would have no cause of action against $B$ for damages. If $\mathrm{B}$ has a locus poenitentiae, so has $\mathrm{A}$. They each have, and should have, the opportunity to reconsider and withdraw. Not until B has crossed the bridge, thereby doing the act called for, and accepting the offer, is a contract born. At that moment, and not one instant before, $\mathrm{A}$ is bound, and there is a unilateral contract. Critics of the doctrine of unilateral contract on the ground that the rule is "hard" on B, forget the primary need for mutuality of withdrawal and in lamenting the alleged hardships of $B$, they completely lose sight of the fact that $B$ has the same right of withdrawal that $A$ has. To the writer's mind, the doctrine of unilateral contract is thus as just and equitable as it is logical. So long as there is freedom of contract and parties see fit to integrate their understanding in the form of a unilateral contract, the courts should not interfere with their evident understanding and intention simply because of alleged fanciful hardship.

Suppose, reverting to the second case, that $B$ completes the act of crossing the bridge after $A$ has told him that the offer 
it withdrawn. Here too, $B$ has no rights against $A$, since $B$ had not accepted the offer until after $A$ had duly communicated to $B$ its revocation. An offer cannot be accepted after it has been revoked. ${ }^{3} \quad \mathrm{~B}$ is laboring under an unrelievable error of law in proceeding to accept an offer which, as far as he was concerned, had ceased to exist.

It will be noted that in the Brooklyn Bridge cases there is no unjust enrichment of $A$ and consequently no occasion for quasicontractual recovery by $B$. Let us assume a different set of facts. Suppose A says to $B$, "If you build a garage on my land, I will give you $\$ 1,000 . "$ There is no interchange of promises, and it is clear that a unilateral contract is contemplated by the parteis. Suppose B starts to build the garage on A's land and after it is one-half completed, A then says to B, "I withdraw my offer." It is clear that B had not yet accepted the offer of $A$ at the time of its revocation, and, therefore, that $B$ is not entitled to recover in an action of contract. B could have ceased building the garage at any time, since he had never agreed to complete it; therefore, $A$ has, and should have, the same privilege to draw back on his side. This conclusion cannot be considered as unjust, for $B$ is not deprived thereby of any right in respect of the unfinished garage. Prima facie, that has become part of A's realty. If it is assumed that it is not a permanent accession to the realty of $A$, then it must be treated as personal property. As neither A nor B contemplated a sale of an unfinished garage, title to the garage remains in $B$ so long as it is incomplete. Hence, on A's withdrawal of his offer, $B$ has the right to retake the unfinished garage in specie, or, if possession is refused him, recover its reasonable value in an action of trover. It is plain, therefore, that a strict adherence to the doctrine of unilateral contract works no hardship on $B$ in this case. It may be, however, that the garage, before completion, became part of the freehold of A, brick by brick. In this event, B may not remove the unfinished garage after $A$ withdraws his offer. But this is so, be it noted, not because A exercised his legal right to withdraw his offer before its acceptance, but because the garage as erected becomes part of A's land, by a rule of the law of real property, and the law will not permit $B$ to remove what no longer

3 Byrne \& Co.v. Van Tienhoven \& Co. (1880) 5 C. P. D. 344 ; Stevenson, Jacques \& Co. v. McLean (I880) 5 Q. B. D. 346; Henthorn v. Fraser, [1892] 2 Ch. 27. 
belongs to him. Yet, in a case like this, it seems that $A$ is unjustly enriched by an improvement to his land, consisting of one-half a garage, if no return therefor is made to $B$. If the law will permit A, without B's consent, to retain this improvement to the land, it is only just that the law should afford $B$ compensation for the improvement he made, even against $A$ 's express dissent. Accordingly, $B$ should be permitted to recover from A (quantum valebat) the reasonable value of the extent to which the land of A is enriched unjustly at B's expense. Such procedure in quasi-contract affords a just and equitable solution of the problem, without offending any rules of logic, clear-thinking, and contract law. An offer contemplating an act as its acceptance is revocable at any time before the act has been performed. Yet, a recovery may be permitted in quasi-contract in any instance, where defendant would be otherwise unjustly enriched at the expense of the plaintiff.

In the case of Offord $v$. Davies, the Court of Common Pleas correctly applies the doctrine of unilateral contract. ${ }^{4}$ The defendants agreed jointly and severally to guarantee for the space of twelve months the due payment of all bills of exchange which the plaintiff might discount for a third party. The offer contemplated a series of unilateral contracts. Each act of discounting would operate as a separate transaction. Before certain bills were discounted, defendants withdrew their offer. The court rightly held that they were within their rights in so acting. The interest in this case lies not only in the opinion of the court, but in the interesting discussion that took place between the Judges and $E$. James, $Q$. C., in the course of the argument of the appeal. Williams, J., said, "Suppose I guarantee the price of a carriage to be built for a third party who, before the carriage is finished and consequently before $I$ am bound to pay for it, becomes insolvent, may I recall my guaranty?" Mr. James replied, "Not after the coach-builder has commenced the carriage." Thereupon, Erle, C. J., said, "Before it ripens into a contract either party may withdraw and so put an end to the matter. But the moment the coach-builder has prepared the materials he would probably be found by the jury to have contracted." Erle, C. J., thus recognized the conception of unilateral

4 (1862) I2 C. B. N. S. 748. The decision is reprinted in Keener, Cases on Contracts (2d ed., Wormser \& Loughran) $39-42$. 
contracts. If A says to $B$, "I will give you $\$ 500$ if you build a carriage for me," A has the right to withdraw until the carriage is built. Not until then would the offer of $A$ be accepted, not until then would it ripen into a contract. Therefore, as the Chief Judge says, until that moment, "either party may withdraw and so put an end to the matter." Sometimes a close question of fact is presented as to whether a bilateral or a unilateral contract was intended by the parties. The Chief Judge shrewdly surmises that if the oral remarks were passed upon by $a$ jury, the jury would infer, if possible, that a bilateral contract had been entered into, in other words that mutual promises had been interchanged, and would-in the usual loose fashion of juries-find the evidence of this in the commencement of work by the coach-builder. If the contract contemplated was unilateral, however, a verdict based upon any such process of deliberation might properly be set aside as against the evidence.

The most curious instance of reasoning on the subject of unilateral contracts is that of the Supreme Court of California in a comparatively recent decision, Los Angeles Traction Co. $v$. Wilshire. ${ }^{5}$ The defendants in that case agreed to pay the plaintiff $\$ 2,000$ on the completion of the plaintiff's street railway. Plaintiff did some work on the railway. Defendants revoked their offer before the railway was completed. It was conceded that the offer contemplated a unilateral contract. The court held that when plaintiff had paid money and had begun work in reliance on the offer, the contract suddenly became bilateral, and held defendants liable. The court said, in effect, that when the consideration-the act of building the street railway-had been partly performed, the contract by some magical process then took on a bilateral character. This is a most astounding doctrine, and the court states no authority in support of its remarkable rule that an offer which, if accepted, would constitute a unilateral contract, becomes a bilateral contract by part performance of the act required. The proposition needs only to be stated to refute itself. Defendants did not ask for any promise from plaintiff. Defendants asked for an act from plaintiff, the completion of a certain street railway. Defendants had an absolute right to impose any condition at all in their offer.

(1902) I35 Cal. 654. The decision is reprinted in Keener, Cases on Contracts (2d ed., Wormser \& Loughran) 42-44. 
It is elementary that an offer must be accepted according to its terms, ${ }^{8}$ and the offer could not be accepted by plaintiff except by building the street railway. Plaintiff had never agreed or promised to build the street railway and would have been under no legal liability to defendants if it had refused to complete the road. Common sense, as well as a decent regard for justice, should surely afford to defendants the same opportunity of withdrawal possessed by plaintiff, and it follows that defendants' notice of revocation should have been held effective.

The writer can see no injustice whatever in the operation of the doctrine of unilateral contract. It is logical in theory, simple in application, and just in result. The principle underlying it was stated accurately by the Common Pleas in 1873 when Brett, J., said, "If I say to another, 'if you will go to York, I will give you $\mathfrak{f r o o}^{\prime}$ ' that is in a certain sense a unilateral contract. He has not promised to go to York but if he goes, it cannot be doubted that he will be entitled to receive the $f 100$. His going to York at my request is a sufficient consideration for my promise." True unilateral contracts are not infrequently met with in the practice of the law. Properly understood, and logically applied, the conception presents few difficulties.

\section{MAURICE Wormser.}

Fordham University School of Law.

${ }^{6}$ Hyde v. Wrench (1840) 3 Beay. 334; Minneapolis \& St. Louis Ry. v. Columbus Rolling Mill (1886) rxg U. S. 149; Wittwer v. Hurwitz (1915) 216 N. Y. 259, 264. An acceptance upon terms varying from those of the offer, no matter how slightly, is a rejection of the offer. Cartmell $v$. Neruton (1881) 79 Ind. I:

7 Great Northern Ry. Co. v. Witham (1873) L. R. 9 C. P. 16, opinion of Brett, J. See also, Biggers v. Ozven (1887) $79 \mathrm{Ga} .658$; Cook v. Casler (Ig03) 87 App. Div. (N. Y.) 8; Butchers' Advocate Co. v. Berkof (I9I6) 94 Misc. (N. Y.) 299. 